\title{
Freshwater amphipods (Gammarus pulex) fossarum) and brown trout as bioindicators for PFC contamination with regard to the aquatic ecological status of a small stream
}

\author{
Ute Windisch ${ }^{1 *} \mathbb{0}$, Fabian Springer ${ }^{1}$ and Thorsten Stahl ${ }^{2}$
}

\begin{abstract}
Background: Per- and polyfluorinated chemicals (PFC) have been in use for more than 60 years. As a result of their high thermal and chemical stability, they have found numerous applications in industrial processes. However, PFC also commonly show disadvantageous properties such as persistence and ubiquitous presence in the environment. The issue of PFC contamination of surface water is addressed in this publication. One aim of this study was to find a potential bioindicator for PFC contamination of small streams, and a second aim was to determine the aquatic ecological quality of such a stream. Standardized methods were used including structural quality mapping of a watercourse, the PERLODES method and electrofishing in four study sections of the stream. PFC contamination was determined in freshwater amphipods (Gammarus pulex/fossarum) and brown trout.
\end{abstract}

Results: This study shows that PFC originating from water contamination can be detected both in amphipods and in internal organs of brown trout. The fingerprints in these two species differ considerably from one another. The highest concentrations of PFC were found in the liver and kidneys of brown trout. The methods used in this study also show that the four study sections of the small stream tested fail to achieve the "good" ecological status required by the Water Framework Directive. In particular, this is due to inadequate benthic invertebrates.

Conclusions: Even though it is not possible to determine a causal relationship between the ecological status of the small stream and the detection of PFC in aquatic organisms, appropriate measures must be developed and applied to reduce the spreading of PFC in the environment. In addition to the brown trout, freshwater amphipods proved to be useful as a bioindicator for PFC contamination of streams. In the future it will be necessary to observe whether the number of species in the benthic invertebrates continue to decline.

Keywords: Bioindication, Accumulation, Per- and polyfluorinated chemicals, Liver, Muscle, Kidney, Benthic invertebrates, Watercourse structure quality, PERLODES method, Aquatic ecological status

${ }^{*}$ Correspondence: ute.windisch@lse.thm.de

1 Technische Hochschule Mittelhessen-University of Applied Sciences, Wiesenstr. 14, 35390 Giessen, Germany

Full list of author information is available at the end of the article

\section{Background}

The term per- and polyfluorinated compounds (PFC) designates anthropogenic chemicals that have been in use for more than 60 years in various industrial processes. This group of substances comprises more than 4730 individual compounds [1]. Due to their special technical properties (a number of them are water and 
dirt repellent, temperature resistant, surface active, chemically very stable and persistent), they find diverse applications [2-4]. PFC are used in a variety of ways, for example in the furniture, paper and textile industry, at fire departments, in agriculture and sports. Among these, perfluorooctane sulfonate (PFOS) and perfluorooctanoic acid (PFOA) constitute the two so-called lead substances that are toxicologically most important and the most widespread in the environment $[5,6]$. Some PFC are enriched in the environment, in plants, humans and animals [7]. The half-life in humans has been shown to be 8.67 years for PFOS [8] and 4.37 years for PFOA [9]. In animal studies, both substances have been shown to be carcinogenic as well as toxic for the liver and for reproduction [10]. Environmental dispersion takes place by different pathways including the water route, since PFC up to a chain length of eight carbon atoms have comparatively good aqueous solubility $[11,12]$. At the same time, PFC contamination can also be shown in soil and in the air. Paths of entry into the environment are, for example, wastewater, fertilizer, sewage sludge or the use of firefighting foams [13]. As a consequence, PFC derived from the soil and water are passed by plants and fed to animals $[14,15]$ and finally to humans $[6,16]$.

PFC have been a wide-ranging environmental topic in Germany since 2006 as a result of studies made on water samples taken from the drainage basin of the Ruhr and Möhne rivers in North Rhine-Westphalia (NRW). This contamination originated from surrounding farmlands on which a so-called "soil improver" that was highly contaminated with PFC had been spread. Farmers unwittingly applied this contaminated fertilizer on their fields over a period of years. It is assumed that use of these PFC-contaminated fertilizers began as early as 2003. The PFC were washed out of the soil by precipitation, reached adjoining streams and consequently found their way into the ground water via leaching $[11,12]$. The Ministry of the Environment, Agriculture, Nature and Consumer Protection of the State of North Rhine-Westphalia (MUNLV NRW) subsequently informed the Hessian Ministry of the Environment, Climate Protection, Agriculture and Consumer Protection (HMUKLV) about the PFC contamination. It was then determined that contaminated fertilizer was spread on fields in Hesse from 2003 to 2006. The State of Hesse then undertook numerous studies on drinking water, surface waters, soil and foodstuffs as well as livestock feed $[17,18]$. While fish are considered good bioindicators for PFC in large surface waters [19], no bioindicators for PFC are available for smaller water bodies with few or no fish. The objective of the present study was to find a suitable bioindicator for PFC contamination for small streams in which possibly no fish exist, and to assess the aquatic ecological status of such a small stream in the Hessian highlands using standardized methods. A stream was chosen with adjoins fields that had been treated with fertilizer containing PFC in the past [20].

\section{Methods}

\section{Survey site}

The survey site is an 8.4- $\mathrm{km}$-long small stream in the Hessian highlands, belonging to the Weser river system and is an oligotrophic highland brook Type 5. The catchment basin of the stream covers an area of about $27 \mathrm{~km}^{2}$ [21].

Four 50-m study sections for sampling were delineated along the course of the small stream (Fig. 1). Section 1 is located near the source of the stream and near a residential area. It is assumed that the PFC contamination hotspot lies to the west of this segment, as confirmed by PFC measurements in the stream water (Table 1). Section 2 is in a forested area. Sections 3 and 4 are near the mouth of the stream.

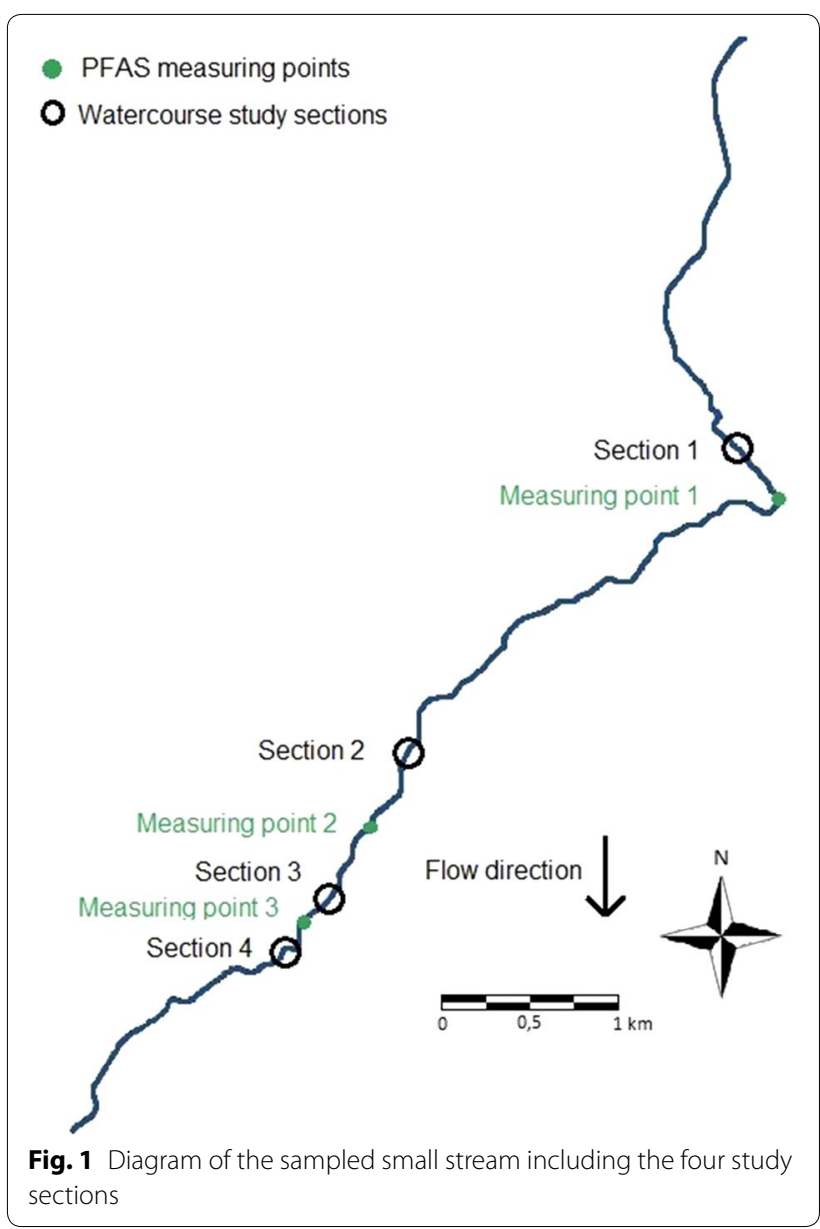


Table 1 Mean and range (in brackets) of PFC concentration in ng/l of stream water from 2012 to 2014 (HLNUG, the authors are in possession of this data)

\begin{tabular}{|c|c|c|c|}
\hline Substance & $\begin{array}{l}\text { Measuring point } 69(n=6) \\
\text { Location near section } 1\end{array}$ & $\begin{array}{l}\text { Measuring point } 77(n=6) \\
\text { Location near section } 2\end{array}$ & $\begin{array}{l}\text { Measuring point } 119(n=6) \\
\text { Location near sections } 3 \text { and } 4\end{array}$ \\
\hline Perfluoropentanoic acid (PFPeA) & $2260(2000-4200)$ & $453(210-740)$ & $6(1-12)$ \\
\hline Perfluorohexanoic acid (PFHxA) & $9933(7000-13,000)$ & $1238(670-2000)$ & $18(11-32)$ \\
\hline Perfluoroheptanoic acid (PFHpA) & $1850(1300-2900)$ & $150(100-230)$ & $4(3-5)$ \\
\hline Perfluorooctanoic acid (PFOA) & 1500 (1100-2200) & $171(69-350)$ & $8(2-10)$ \\
\hline Perfluorononanoic acid (PFNA) & $<\mathrm{LOQ}^{\mathrm{a}}$ & $<\mathrm{LOQ}$ & $<$ LOQ \\
\hline Perfluorodecanoic acid (PFDA) & $<L O Q$ & $<$ LOQ & $<L O Q$ \\
\hline Perfluorobutane sulfonate (PFBS) & $41(<\mathrm{LOQ}-110)$ & $8(6-10)$ & $<\mathrm{LOQ}$ \\
\hline Perfluorohexane sulfonate (PFHxS) & $0.5(<\mathrm{LOQ}-2)$ & $<$ LOQ & $<\mathrm{LOQ}$ \\
\hline Perfluorooctane sulfonate (PFOS) & $0.5(<\mathrm{LOQ}-2)$ & $<L O Q$ & $<L O Q$ \\
\hline
\end{tabular}

a Limit of quantification (LOQ) for all substances: $1 \mathrm{ng} / \mathrm{l}$

\section{Structure quality}

The structural quality at the studied survey sites was assessed using the method proposed by the German Working Group on Water Issues of the Federal States and the Federal Government [22]. Analyzed stream stretches are assigned to quality classes ranging from 1 (not modified) to 7 (completely modified). The quality of the water structure plays an important role in the self-purification capacity as well as the biodiversity of a body of water. The benchmark for evaluation is the Current Potential Ecological Status of surface water (CPES). The CPES is a description of the state of a body of water that would occur after removal of all obstructions and uses and which would be evaluated as quality grade 1 . The quality of water structure was recorded on-site for each of the four study sections with the help of assessment questionnaires, and was then subsequently evaluated.

\section{Macroinvertebrate community and ecological status classes}

A record of benthic macroinvertebrates is of major significance in the study of the biological components of a body of water [23]. PERLODES is the German standardized system for assessing the macroinvertebrate community. The actual species diversity in the analyzed stream is compared with the expected species diversity for the particular type of body of water and consequently evaluated, allowing conclusions about certain stress factors. This methodology is described in detail in Meier et al. [24]. Sampling was performed according to the PERLODES method for all four study sections. The invertebrates collected were classified in the laboratory according to Bauernfeind and Humpesch [25], LANUV [26], Nagel [27], Sundermann and Lohse [28] and Waringer and Graf [29]. Computer-assisted evaluation was performed using the software ASTERICS 4.0.4 [30].

\section{Sampling of bioindicator organisms on-site}

Electrofishing was used to obtain samples of trout. The basis for the procedure is the passive monitoring of fish as an indicator of accumulation VDI 4230 Blatt 4 [31]. Sampling of fish by electrofishing was performed in November of 2018 according to DIN EN 14011 [32]. The procedure was carried out by trained technical personnel with appropriate equipment. Fishing in the study sections was performed against the flow using direct current. Six brown trout (Salmo trutta fario) were collected from each of the study sections 2,3 and 4 . No fish were found in section 1. Freshwater amphipods (Gammarus pulex/ fossarum) were also collected at each of the sections 1 to 4 using a landing net by kick sampling (Fig. 2). It was not possible to make an on-site classification between the two species of amphipod (Gammarus pulex/fossarum), because it is not possible to differentiate between these species with the unaided eye.

\section{Sampling and sample analysis}

After sample collection the freshwater amphipods were transferred to $96 \%$ ethanol and the brown trout placed in coolers with ice $\left(-10^{\circ} \mathrm{C}\right)$ for interim storage. Subsequent storage of the samples was at the THM (Technische Hochschule Mittelhessen). The amphipods were rinsed with demineralized water to remove the alcohol, weighed on an analytical balance and dried to constant weight in a drying cabinet by $40{ }^{\circ} \mathrm{C}$ for $36 \mathrm{~h}$. Drying resulted in a weight loss of about $90 \%$ (Table 2). The amphipod samples were stored until analysis at room temperature in glass jars with snap-on plastic lids. The brown trout were stored frozen at $-18^{\circ} \mathrm{C}$ in plastic bags.

The amphipod and trout samples were sent to the Bavarian Agency for Health and Food Safety (LGL) for preparation and analysis. The individual species (or organs) were pooled, processed and subsequently 

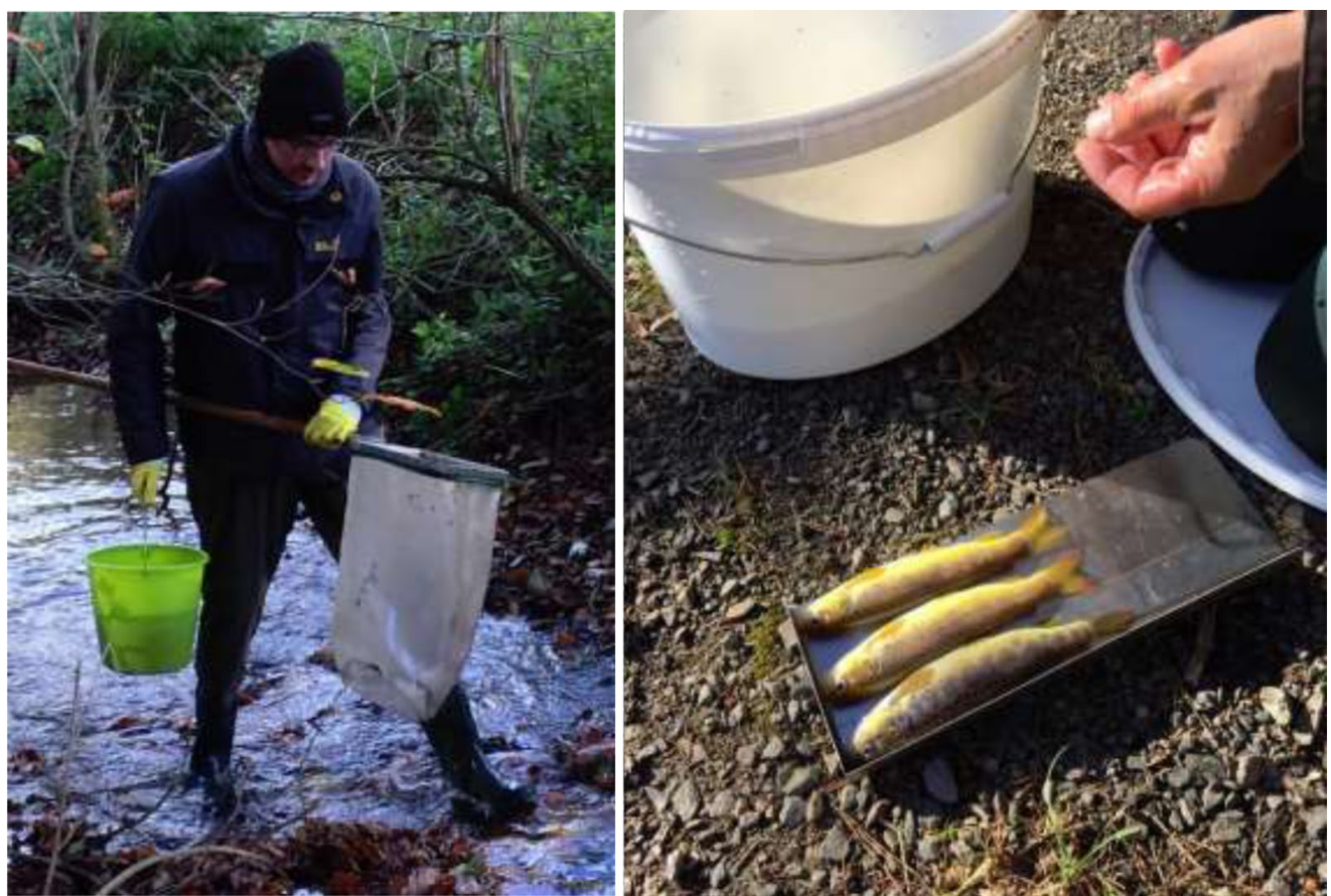

Fig. 2 Sampling of freshwater amphipods by kick sampling with a net (left) and brown trout caught by electrofishing (right)

Table 2 Weight determination of amphipods (Gammarus pulex/fossarum) with comparison of wet and dry weights

\begin{tabular}{lcccc}
\hline & Section 1 & Section 2 & Section 3 & Section 4 \\
\hline Wet weight (g) & 12.6 & 13.1 & 11.5 & 12.1 \\
Dry weight (g) & 1.12 & 1.25 & 1.02 & 1.17 \\
Weight loss (\%) & 91.1 & 90.4 & 91.1 & 90.3 \\
\hline
\end{tabular}

homogenized. The skin was removed from fish muscle tissue before processing. Homogenization of the tissue was performed with a table-top cutter (robot coupe R3-3000; Vincennes Cedex, France). Liver and kidney tissue was homogenized with a metal spatula. The amphipod samples were crushed and simultaneously homogenized in a ceramic mortar with ceramic pestle (Bauscher, Weiden, Germany). Sample weight for fish muscle, liver and kidney was $1 \mathrm{~g}$ and for the amphipods $0.25 \mathrm{~g}$ per sample. All samples underwent a single determination. Further processing of the samples was performed in the same manner: use of the Quick-Easy-Cheap-Effective-RuggedSafe-method (QuEChERS) allows a cost-effective and rapid determination of a large number of samples with regard to pesticides and similar substances [33]. A modified variant of the QuEChERS method was applied. The following isotope-labeled standards were first added to the samples at a concentration of $50 \mu \mathrm{g} / \mathrm{ml}$ in methanol $( \pm 2.5 \mu \mathrm{g} / \mathrm{ml})$ : (perfluoro- $n-\left(1,2,3,4-{ }^{13} \mathrm{C}_{4}\right)$ butanoic acid, perfluoro-n- $\left[3,4,5-{ }^{13} \mathrm{C}_{3}\right]$ pentanoic acid, perfluoro$n-\left(1,2-{ }^{13} C_{2}\right)$ hexanoic acid, perfluoro- $n-\left[1,2,3,4-{ }^{13} C_{4}\right]$ heptanoic acid, perfluoro- $n-\left(1,2,3,4-{ }^{13} \mathrm{C}_{4}\right)$ octanoic acid, perfluoro- $n-\left(1,2,3,4,5-{ }^{13} C_{5}\right)$ nonanoic acid, perfluoro$n$ - $\left(1,2-{ }^{13} \mathrm{C} 2\right)$ decanoic acid, perfluoro- $n-\left(1,2-{ }^{13} \mathrm{C}_{2}\right)$ undecanoic acid, perfluoro- $n-\left(1,2-{ }^{13} \mathrm{C}_{2}\right)$ dodecanoic acid, Sodium perfluoro-1-[2,3,4- $\left.{ }^{13} \mathrm{C}_{3}\right]$-butanesulfonate, sodium perfluoro-1-hexane $\left[{ }^{18} \mathrm{O}_{2}\right]$ sulfonate, sodium perfluoro-1-[1,2,3,4- $\left.{ }^{13} \mathrm{C}_{4}\right]$-octanesulfonate, concentration (all standards obtained from Wellington Laboratories, Canada). A specific isotope-labeled standard was used for subsequent quantification of each analyte. Ten milliliter of ultra-pure water (Merck Millipore, Darmstadt, Deutschland) was then added to each sample, and in the case of the freshwater amphipods the samples were soaked to swell in an ultrasonic bath (Bandelin, Sonorex, Berlin, Germany) for $10 \mathrm{~min}$. After addition of $10 \mathrm{ml}$ acetonitrile (LC-MS Grade, Fisher Scientific, Schwerte, Germany) the samples were manually shaken for $1 \mathrm{~min}$. The samples were then once again placed in the ultrasonic bath followed by treatment with unbuffered salt tube (Supel ${ }^{\mathrm{TM}}$ QuE, Sigma Aldrich, Steinheim, Germany), shaking and centrifugation (10 min at $1000 \mathrm{~g}$ ) (Eppendorf Centrifuge 5810 R, Wesseling-Berzdorf, Germany). The aliquot acetonitrile phase was subsequently collected and $200 \mu \mathrm{l}$ water added. The samples were then concentrated down to $200 \mu \mathrm{l}$ in a stream of nitrogen (Barkey, Leopoldshöhe, Germany) at $40{ }^{\circ} \mathrm{C}$. 
An acetonitrile-methanol-mixture (v/v, 1:1) was added for a final volume of $400 \mu \mathrm{l}$ (methanol hypergrade for LC-MS, Merck, Darmstadt, Germany). The samples were homogenized by shaking on a laboratory shaker (Vortex-Genie-2, Scientific Industries, Inc., Bohemia, New York, USA). Sample analysis was performed by LCMS/MS (liquid chromatography-mass spectrometry/ mass spectrometry) $[19,34]$ on an API 3000 (AB Sciex, Ontario, Canada). A mixture of water, acetonitrile and ammonium acetate served as eluent. For the LC-MS/ MS a gradient-elution column: Gemini $3 \mu \mathrm{m} \mathrm{C} 18110 \mathrm{~A}^{\circ}$ $(100 \mathrm{~mm} \times 2 \mathrm{~mm}, \mathrm{Fa}$. Phenomenex, Aschaffenburg, Germany (reversed phase, $18 \mathrm{C}$-atoms in the side-chain) was used with a precolumn Gemini C18 $(4 \times 2 \mathrm{~mm}$, Fa. Phenomenex) ESI (electrospray-ionization). The uncertainty of measurement was also determined, calculated from the coefficient of variation and the instrumental deviation. The coefficient of variation was determined by dividing the individual samples into 6 portions. The expanded measurement uncertainty was obtained by multiplying the coefficient of variation by a factor of 2 . Since all values were $50 \%$ below the measurement uncertainty, in the interest of comparability of the values the analytical laboratory defined an expanded measurement uncertainty of $50 \%$.

\section{Results and discussion}

\section{Structural quality}

Mapping of the structural qualities was performed onsite in May of 2018. None of the study segments of the small stream were in use for any activities such as sports. The width of the stream is between 1 and $5 \mathrm{~m}$ in all sections and the sections are all of the wide river system type. The results of mapping are shown in Table 3.

The results show that the water structure in three of four segments is in unaltered state and therefore supports the achievement of an ecologically "good" status according to the European Water Framework Directive. Study section 1 is the only one showing alterations. This is mostly the result of this section being in close proximity to a residential area, and therefore underwent minor straightening. As a consequence, this section does not display a "natural profile", resulting in degradation in the overall evaluation [22].

\section{Macroinvertebrate community and ecological status classes}

The PERLODES method was carried out on-site from March 11 to March 13 in 2018. Substrate mapping showed that three of the four sections exhibit large substrate diversity. Section 1 showed the least substrate diversity of all. In this section sand and/or mineral sludge (Psammal/Psammopelal) dominate, together with submerged aquatic plants (macrophytes). Common substrates in the sections 2, 3 and 4 were fine to medium gravel (Akal) as well as stones of various sizes (macro-, meso-, microlithal). The substrates found correspond for the most part with the description of a stream Type 5 (coarse material rich siliceous highland stream) [35]. Straightening of the watercourse eliminated the possibility of forming a semi-natural embankment structure. In addition, the stream bed is deeper, resulting in reduced substrate diversity [36].

Three aspects (designated as "modules") were considered in the evaluation of the ecological state indicated by macroinvertebrates (Table 4). The module with the lowest ranking determines the overall result ("worst-case principle") [24]. The module "general degradation" presented the "worst case" for each of the four investigated

Table 4 Evaluation of the ecological status based on three modules

\begin{tabular}{|c|c|c|c|c|}
\hline & Section 1 & Section 2 & Section 3 & Section 4 \\
\hline Module saprobity & Good & Good & Good & Good \\
\hline Module acidification & Very good & Very good & Very good & Very good \\
\hline $\begin{array}{l}\text { Module general degra- } \\
\text { dation }\end{array}$ & Bad & Poor & Poor & Poor \\
\hline $\begin{array}{l}\text { Module ecological } \\
\text { status }\end{array}$ & Bad & Poor & Poor & Poor \\
\hline
\end{tabular}

Table 3 Results of structure quality mapping in all four investigation segments

\begin{tabular}{|c|c|c|c|c|}
\hline & Section 1 & Section 2 & Section 3 & Section 4 \\
\hline Channel pattern & Weakly altered & Weakly altered & Weakly altered & Unaltered \\
\hline Longitudinal profile & Weakly altered & Weakly altered & Weakly altered & Weakly altered \\
\hline Transverse profile & Weakly altered & Weakly altered & Weakly altered & Unaltered \\
\hline Streambed structure & Moderately altered & Unaltered & Unaltered & Unaltered \\
\hline Embankment structure & Moderately altered & Unaltered & Unaltered & Unaltered \\
\hline Water-body environment & Weakly altered & Unaltered & Unaltered & Weakly altered \\
\hline Overall evaluation & Moderately altered/grade 3 & Unaltered/grade 1 & Unaltered/grade 1 & Unaltered/grade 1 \\
\hline
\end{tabular}


sections. Thus section 1 was evaluated as "bad", and segments 2 to 4 were evaluated as "poor" (Table 4).

The results of the module "saprobity", "acidification" and "general degradation" are assured, meaning that indicator taxa for each of the four study sections were adequately abundant [37]. The module "saprobity" was evaluated as "good" for all four sections. This indicates that organic pollution in the water as well as the resulting oxygen depletion is minor [37]. The module "acidification" was evaluated as "very good" for all four sections. Streams of the Type 5 generally tend toward acidification. This circumstance counteracts the geological substrate in the regions examined. The rocks in the substrate are alkaline, and thus counter the acidification of the stream water [37]. The "general degradation" describes the impact of various stressors and consists of the following metrics ( $\mathrm{FI}=$ fauna-index; $\mathrm{HR}=$ hyporhithral colonizers; $\mathrm{EPT}=$ Ephemeroptera, Plecoptera, Trichoptera; $\mathrm{RI}=$ rheo index). These metrics are influenced by the structural diversity, the composition of the habitat, flow conditions, sedimentation and the density of the microhabitats within the stream [37, 38]. Specific results of the metrics for each section are shown in Table 5 .

The results in the module "general degradation" indicate structural deficits. In particular section 1 received a bad evaluation. Sections $2-4$ are evaluated as poor. The main reason for this is the lack of indicator species such as, for example, mayflies (Ephemeroptera). This condition

Table 5 Results of the metrics for the module "general degradation"

\begin{tabular}{|c|c|c|c|c|}
\hline & Section 1 & Section 2 & Section 3 & Section 4 \\
\hline Fauna index & Bad & Poor & Poor & Poor \\
\hline Hyporhithral colonizers & Poor & Poor & Poor & Poor \\
\hline $\begin{array}{l}\text { Ephemeroptera, } \\
\text { Plecoptera, Trichop- } \\
\text { tera }\end{array}$ & Bad & Poor & Poor & Poor \\
\hline Rheo index & Bad & Moderate & Moderate & Poor \\
\hline $\begin{array}{l}\text { Overall result } \\
\text { Score }(0-1)\end{array}$ & $\begin{array}{l}\text { Bad } \\
0.17\end{array}$ & $\begin{array}{l}\text { Poor } \\
0.32\end{array}$ & $\begin{array}{l}\text { Poor } \\
0.31\end{array}$ & $\begin{array}{l}\text { Poor } \\
0.30\end{array}$ \\
\hline
\end{tabular}

is an indication of a stream type with inadequate macrobenthic community [37, 38]. Section 4 showed the largest biodiversity with 23 species present. This species diversity could not positively affect the overall evaluation, however. Section 1 received the worst evaluation as a result of minimal substrate diversity and the poor rating in the module "general degradation". Macrobenthic studies were undertaken on sections 2 and 4 by the Hessian State Office for Nature Conservation, Environment and Geology (HLNUG) in March 2005 and April 2007. The results of those studies are compared with the results from the present study in Table 6.

Although more than 10 years have passed, the values for the modules "saprobity" and "acidification" have remained the same. In contrast, however, differences are observed in the module "general degradation". Whereas section 2 received an evaluation of "good" in the year 2007, section 4 received a rating of moderate, also showing deficits at that time. As seen in Table 4 as a result of the worst-case evaluation, the module "general degradation" is the determining factor in the overall evaluation. Whereas 34 Taxa were found in the year 2007, only 21 were seen in 2018. In 2005, a total of 41 taxa were registered in section 4; in 2018 there were only 23 [21]. The differences may be a result of new stressors such as climate change and agricultural pollutants [39]. As a further possible consequence, displacement of more sensitive by less-sensitive species could have taken place. Additionally, the PFC pollution, which presumably occurred between 2003 and 2006, could come into question as a cause of the loss of species diversity [10].

In addition to data on species diversity, the PERLODES method also comprises an estimation of abundance and can therefore serve as a basis for choosing an appropriate bioindicator. In all four study sections, the order Amphipoda (freshwater amphipods) make up the largest proportion of all taxa found ( $>50 \%$ of the total), as seen in Fig. 3, for example. This order comprised solely the species Gammarus pulex and Gammarus fossarum. Since these species make up the largest part of the biomass they prove to be suitable bioindicators for the accumulation of PFC contamination. This is also true for the sections

Table 6 Comparison of ecological status class from the present study with results from the HLNUG studies from the year 2005 (section 4) and 2007 (section 2) [21])

\begin{tabular}{|c|c|c|c|c|}
\hline \multirow[t]{2}{*}{ Time point of sampling } & \multicolumn{2}{|l|}{ Section 2} & \multicolumn{2}{|l|}{ Section 4} \\
\hline & HLNUG 2007 & 2018 & HLNUG 2005 & 2018 \\
\hline Module saprobity & Good & Good & Good & Good \\
\hline Module general degradation & Good & Unsatisfactory & Moderate & Unsatisfactory \\
\hline Module acidification & Very good & Very good & Very good & Very good \\
\hline Ecological status & Good & Unsatisfactory & Moderate & Unsatisfactory \\
\hline
\end{tabular}




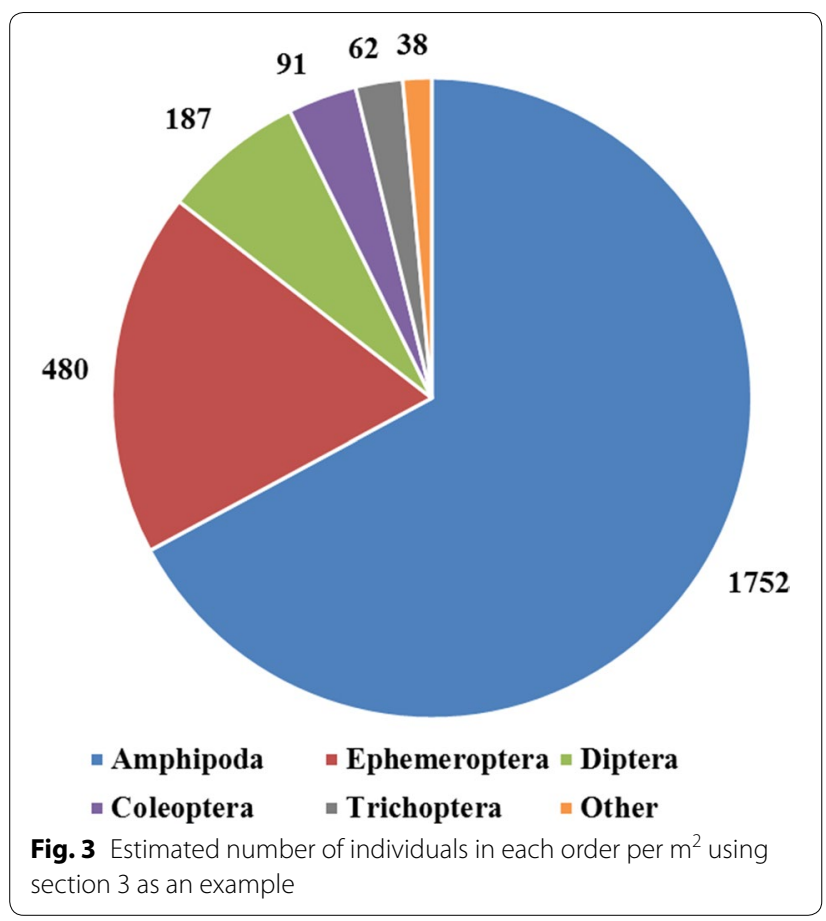

evaluated as "poor" as well as those with an aquatic ecological status of "unsatisfactory".

\section{PFC concentrations in freshwater amphipods and brown trout}

The results of the PFC analyses in freshwater amphipods (Gammarus pulex/fossarum) and brown trout are presented in Tables 7, 8, 9, 10. The results are organized according to study section, whereby no trout were found in section 1 . This is possibly the result of the steep V-shaped slope, too shallow water and a relatively straight physical structure of the small stream, which is unattractive to trout because it does not provide shelter
Table 8 Results of the PFC analysis of brown trout liver in $\mu \mathbf{g} / \mathbf{k g}$

\begin{tabular}{llll}
\hline & Section 2 & Section 3 & Section 4 \\
\hline Perfluoropentanoic acid (PFPeA) & $<$ LOQ $^{\mathrm{a}}$ & $<\mathrm{LOQ}$ & $<\mathrm{LOQ}$ \\
Perfluorohexanoic acid (PFHXA) & $4.4 \pm 2.2$ & $9.9 \pm 5.0$ & $8.5 \pm 4.3$ \\
Perfluoroheptanoic acid (PFHpA) & $2.0 \pm 1.0$ & $3.1 \pm 1.6$ & $5.0 \pm 2.5$ \\
Perfluorooctanoic acid (PFOA) & $59 \pm 30$ & $53 \pm 27$ & $101 \pm 51$ \\
Perfluorononanoic acid (PFNA) & $2.3 \pm 1.2$ & $1.9 \pm 1.0$ & $1.5 \pm 0.8$ \\
Perfluorodecanoic acid (PFDA) & $3.8 \pm 1.9$ & $2.6 \pm 1.3$ & $2.1 \pm 1.1$ \\
Perfluorooctane sulfonate (PFOS) & $15.1 \pm 7.6$ & $13.1 \pm 6.6$ & $7.7 \pm 3.9$ \\
\hline
\end{tabular}

${ }^{a}$ Limit of quantification (LOQ) perfluoropentanoic acid: $2 \mu \mathrm{g} / \mathrm{kg}$

or resting areas. In addition, for spawning trout need loose gravel sediment in which to form their spawning pits. Fine bottom substrate, as found in section 1 is not suitable for spawning [40]. The PFC concentrations of the various measurements are graphically presented in Figs. 4, 5, 6, 7.

\section{Freshwater amphipods}

In all study sections, adequate numbers of freshwater amphipods could be obtained. The PFC concentrations measured in these amphipods are presented in Table 7.

In addition to the PFC substances listed in Table 7, the following substances were analyzed: perfluorononanoic acid (PFNA), perfluorodecanoic acid (PFDA), perfluoroundecanoic acid (PFUnDA), perfluorododecanoic acid (PFDDA), perfluorobutanesulfonic acid (PFBS), perfluorohexane sulfonate (PFHxS), PFOA-surrogate (KDONA), 6:2 fluorotelomer sulfonic acid (6:2-FTS) und 8:2 fluorotelomer sulfonic acid (8:2-FTS). The concentrations of these substances, however, were below the limit of quantification. Figure 4 shows a graphic representation of the PFC concentrations in freshwater amphipods.

Of particular note is the high concentration of PFOA, especially in section 1 , but also apparent in sections 2 and

Table 7 Result of the PFC determinations in freshwater amphipods (Gammarus pulex/fossarum) in $\mu \mathrm{g} / \mathrm{kg}$

\begin{tabular}{|c|c|c|c|c|}
\hline & Section 1 & Section 2 & Section 3 & Section 4 \\
\hline Perfluorobutanoic acid (PFBA) & $<\mathrm{LOQ}^{\mathrm{a}}$ & $<L O Q$ & $<L O Q$ & $<L O Q$ \\
\hline Perfluoropentanoic acid (PFPeA) & $16.4 \pm 8.2$ & $12.4 \pm 6.2$ & $<\mathrm{LOQ}^{\mathrm{b}}$ & $<\mathrm{LOQ}$ \\
\hline Perfluorohexanoic acid (PFHxA) & $41 \pm 21$ & $23 \pm 12$ & $<\mathrm{LOQ}^{\mathrm{c}}$ & $<\mathrm{LOQ}$ \\
\hline Perfluoroheptanoic acid (PFHpA) & $18.4 \pm 9.2$ & $7.7 \pm 3.9$ & $4.8 \pm 2.4$ & $<\mathrm{LOQ}^{\mathrm{d}}$ \\
\hline Perfluorooctanoic acid (PFOA) & $211 \pm 106$ & $84 \pm 42$ & $65.0 \pm 32.5$ & $12.6 \pm 6.3$ \\
\hline Perfluorooctane sulfonate (PFOS) & $<\mathrm{LOQ}^{\mathrm{e}}$ & $<\mathrm{LOQ}$ & $<\mathrm{LOQ}$ & $<L O Q$ \\
\hline
\end{tabular}

a Limit of quantification (LOQ) perfluorobutanoic acid: $14 \mu \mathrm{g} / \mathrm{kg}$

b Limit of quantification (LOQ) perfluoropentanoic acid: $12 \mu \mathrm{g} / \mathrm{kg}$

c Limit of quantification (LOQ) perfluorohexanoic acid: $8 \mu \mathrm{g} / \mathrm{kg}$

d Limit of quantification (LOQ) perfluoroheptanoic acid: $4 \mu \mathrm{g} / \mathrm{kg}$

e Limit of quantification (LOQ) perfluorosulfonic acid: $2 \mu \mathrm{g} / \mathrm{kg}$ 
Table 9 Results of PFC determination in brown trout muscle in $\mu \mathrm{g} / \mathbf{k g}$

\begin{tabular}{|c|c|c|c|}
\hline & Section 2 & Section 3 & Section 4 \\
\hline $\begin{array}{l}\text { Perfluorooctanoic } \\
\text { acid (PFOA) }\end{array}$ & $5.4 \pm 2.7$ & $3.7 \pm 1.9$ & $10.9 \pm 5.5$ \\
\hline $\begin{array}{l}\text { Perfluorooctane } \\
\text { sulfonate (PFOS) }\end{array}$ & $1.1 \pm 0.6$ & $<\mathrm{LOQ}^{\mathrm{a}}$ & $<\mathrm{LOQ}$ \\
\hline
\end{tabular}

Table 10 Results of PFC determination in brown trout (kidney) in $\mu \mathrm{g} / \mathbf{k g}$

\begin{tabular}{llll}
\hline & Section 2 & Section 3 & Section 4 \\
\hline Perfluoropentanoic acid (PFPeA) & $<\mathrm{LOQ}^{\mathrm{a}}$ & $<\mathrm{LOQ}$ & $<\mathrm{LOQ}$ \\
Perfluorohexanoic acid (PFHXA) & $5.6 \pm 2.6$ & $4.4 \pm 2.2$ & $5.7 \pm 2.9$ \\
Perfluoroheptanoic acid (PFHpA) & $2.3 \pm 1.2$ & $3.0 \pm 1.5$ & $4.1 \pm 2.1$ \\
Perfluorooctanoic acid (PFOA) & $59.0 \pm 29.5$ & $58 \pm 29$ & $84 \pm 42$ \\
Perfluorononanoic acid (PFNA) & $2.9 \pm 1.5$ & $2.4 \pm 1.2$ & $<\mathrm{LOQ}^{\mathrm{b}}$ \\
Perfluorodecanoic acid (PFDA) & $5.0 \pm 2.5$ & $3.6 \pm 1.8$ & $2.3 \pm 1.2$ \\
Perfluorooctane sulfonate (PFOS) & $16.3 \pm 8.2$ & $14.6 \pm 7.3$ & $6.5 \pm 3.3$
\end{tabular}

a Limit of quantification (LOQ) perfluorononanoic acid: $1.5 \mu \mathrm{g} / \mathrm{kg}$

b Limit of quantification (LOQ) perfluoropentanoic acid: $1.5 \mu \mathrm{g} / \mathrm{kg}$
3. It is also quite evident that PFC concentrations decline from sections 1 to 4 . This trend is evident for PFOA, as well as for PFHpA, PFHxA and total PFC concentration. This indicates that the greatest PFC concentration is section 1 and is thus in the area of the suspected PFC contamination. PFBA and PFPeA were only found in sections 1 and 2 . PFOS was only determined in trace levels.

\section{Brown trout liver tissue}

Analysis was performed on brown trout that were caught in sections 2 to 4 . The PFC concentrations in the livers are shown in Table 8. In addition to the PFC substances listed in the table the following substances were tested: perfluorononanoic acid (PFNA), perfluorodecanoic acid (PFDA), perfluoroundecanoic acid (PFUnDA), perfluorododecanoic acid (PFDDA), perfluorobutanesulfonic acid (PFBS), perfluorohexane sulfonate (PFHxS), perfluorooctane sulfonate (PFOS linear) PFOA-surrogate (KDONA), 6:2 fluorotelomer sulfonic acid (6:2-FTS) und 8:2 fluorotelomer sulfonic acid (8:2-FTS). The concentrations of these substances, however, were below the limit of quantification and are therefore not listed.

By comparison with the results in Fig. 4 (freshwater amphipods), it can be seen that higher concentrations of PFOA are found in the liver of brown trout. PFOS and PFHxA are present in low concentrations. PFPeA, PFHpA, as well as PFNA and PFDA are found in very low concentrations (Fig. 5).

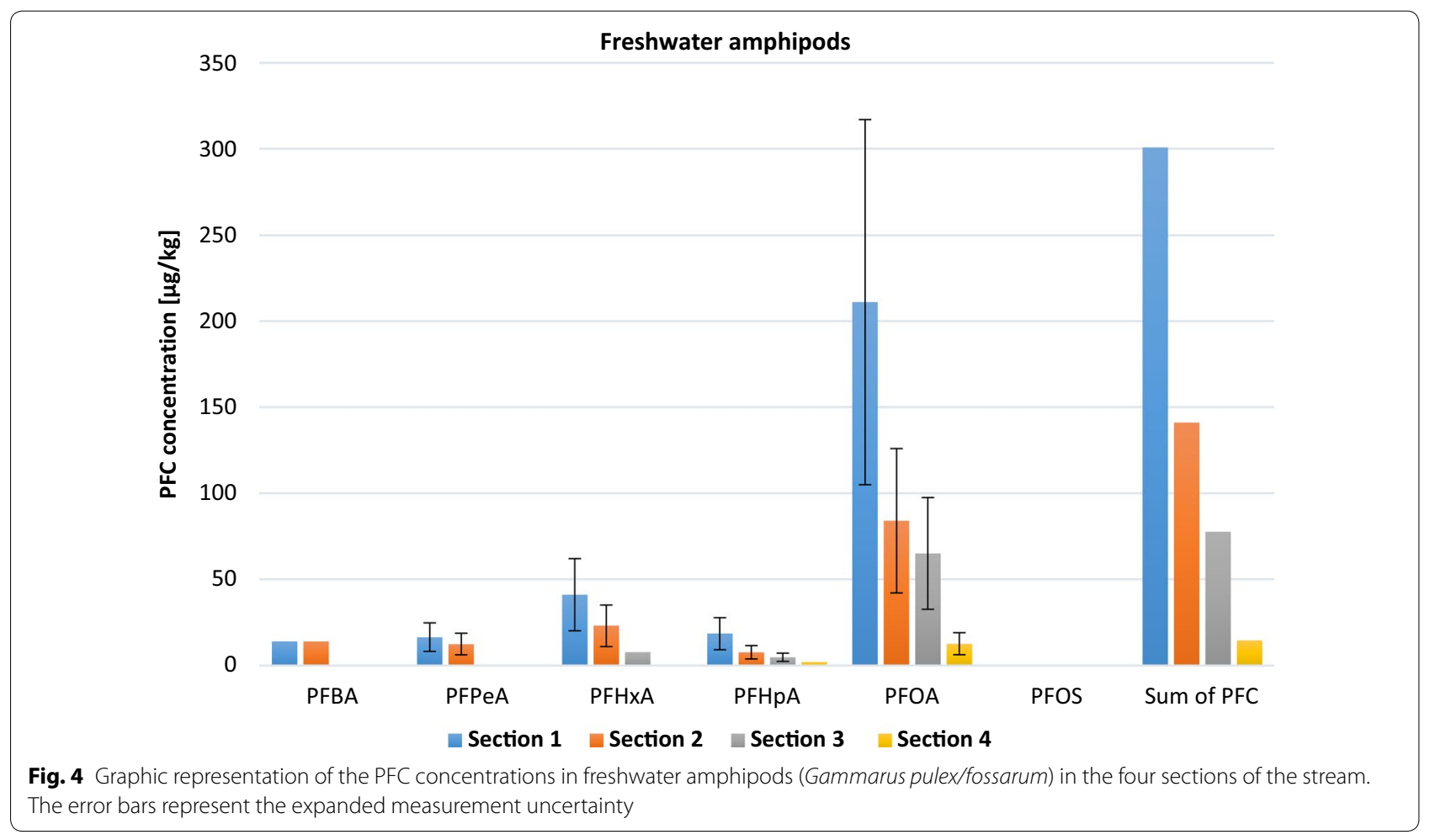




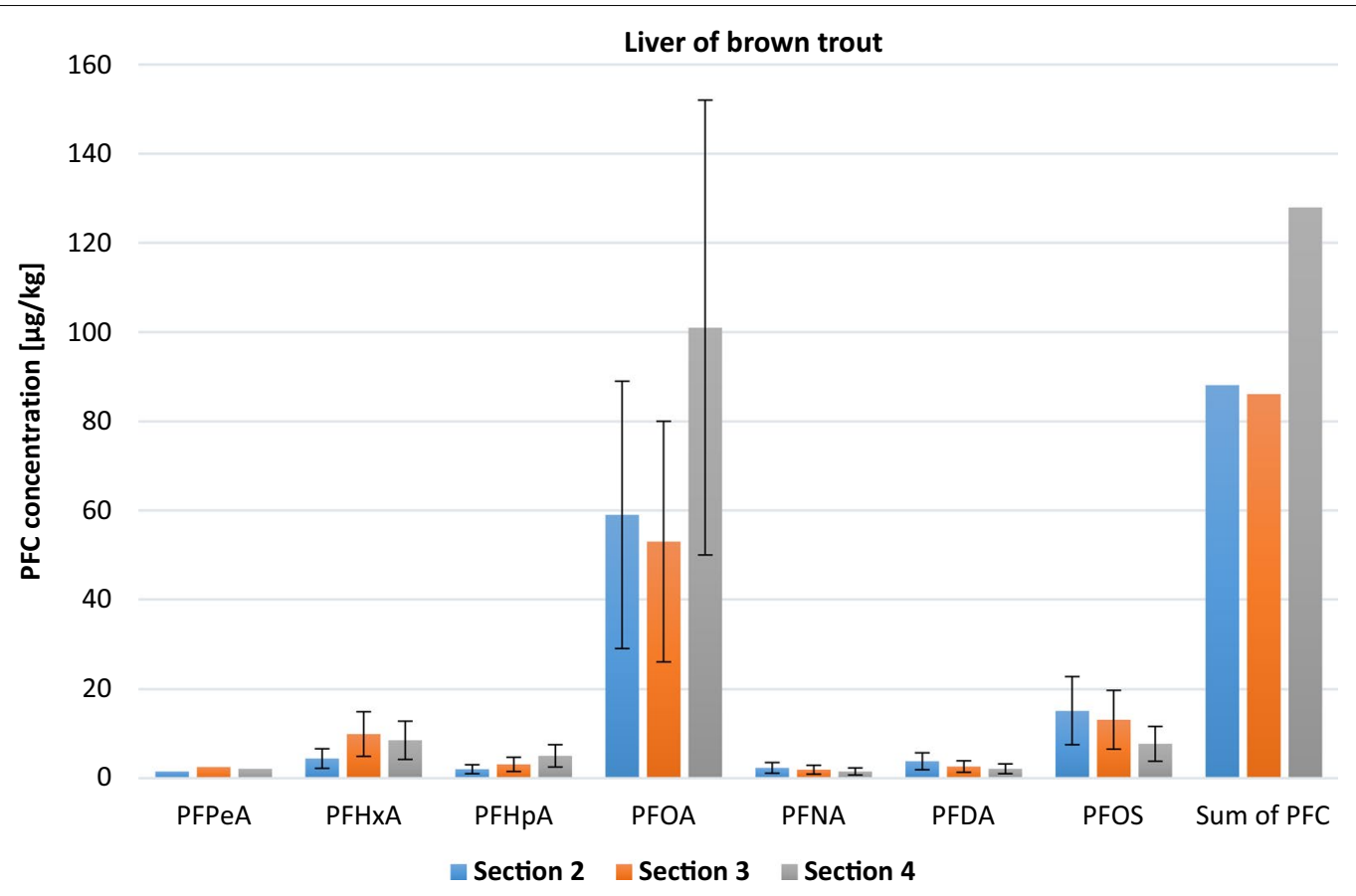

Fig. 5 Graphic representation of the PFC concentrations in brown trout livers in the four sections of the stream. The error bars represent the expanded measurement uncertainty

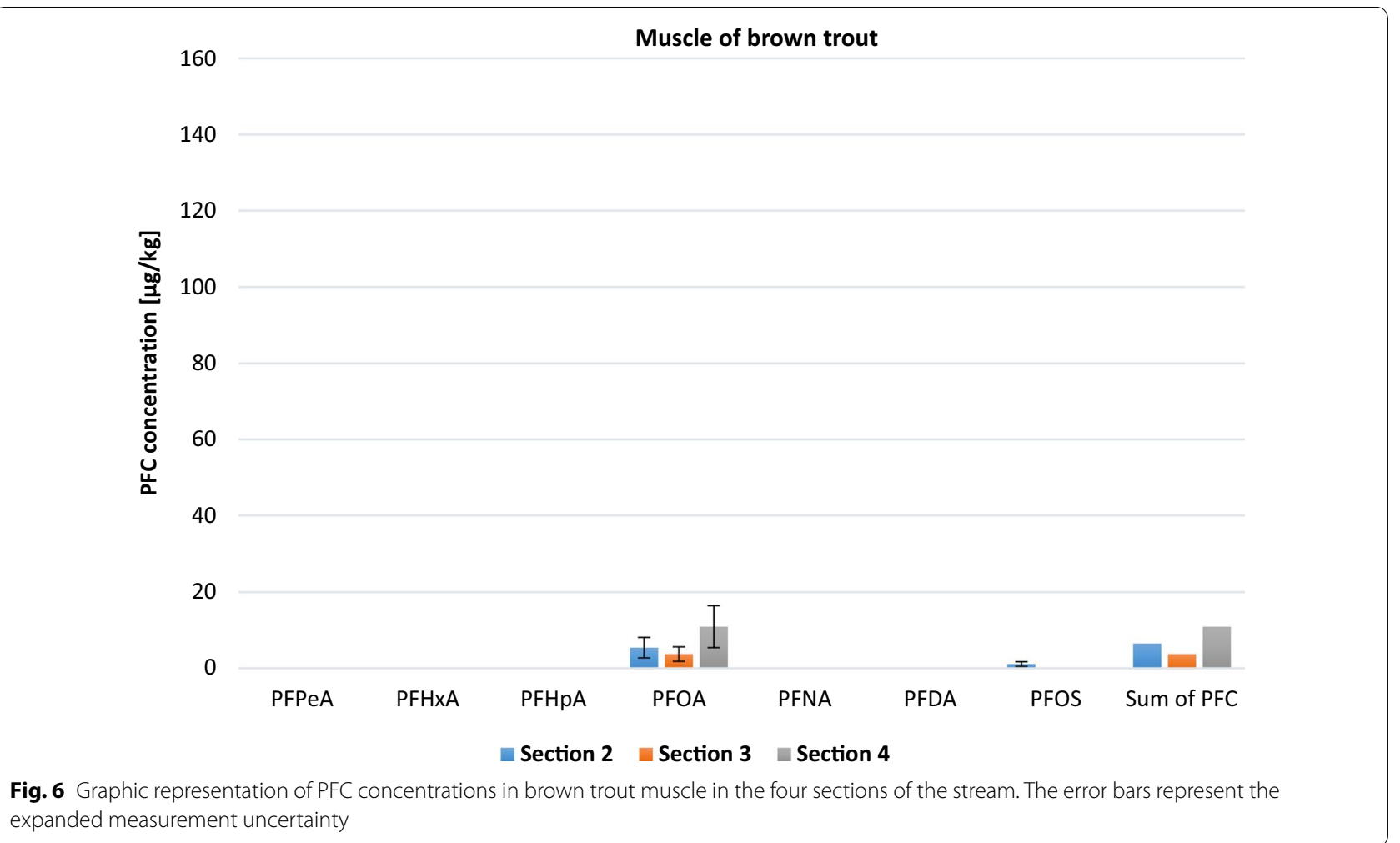




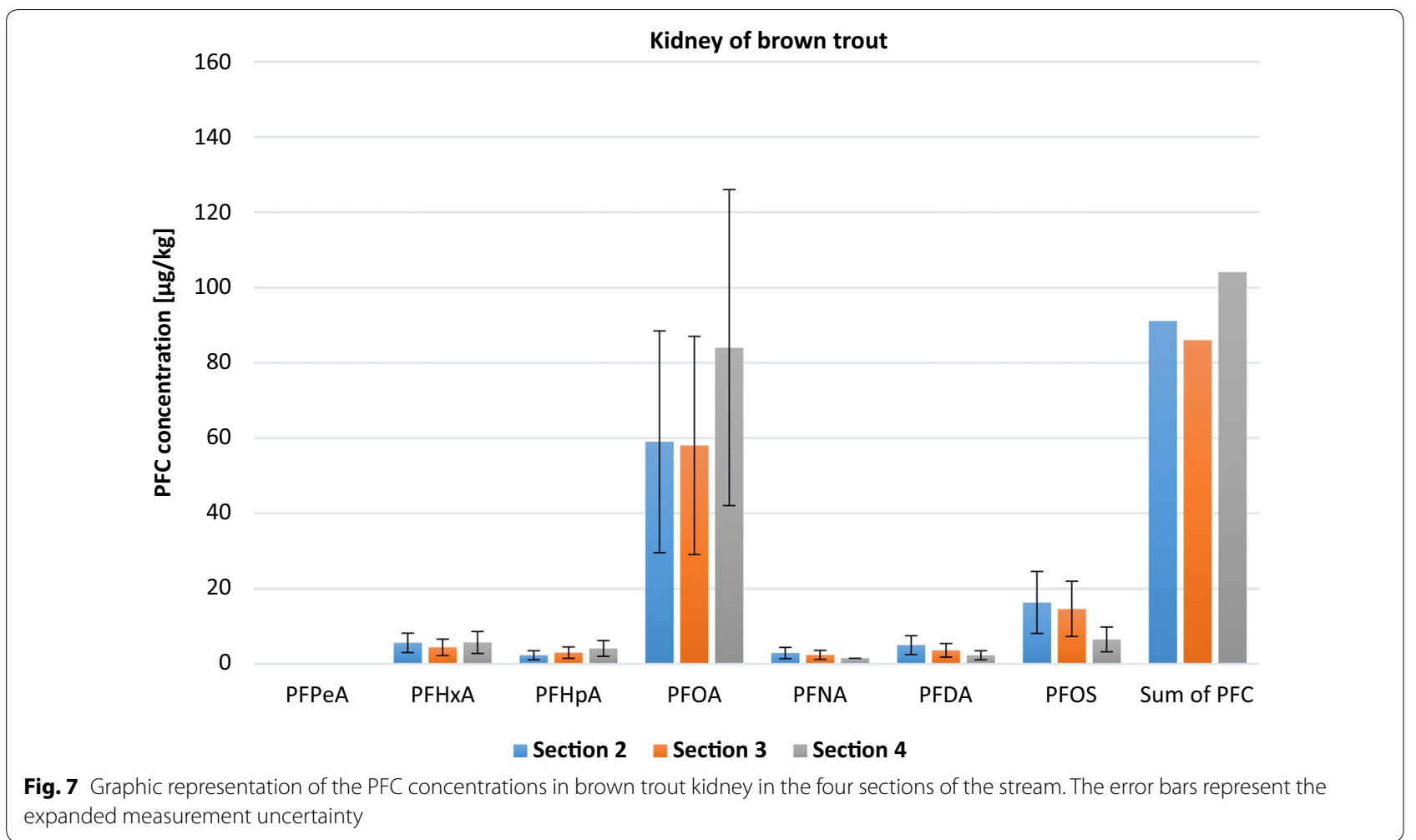

In contrast to freshwater amphipods (Fig. 4), however, no clear concentration gradient was found along the four sections for the trout liver data. Nonetheless, just as with freshwater amphipods, the PFC sum concentration was greatest in section 4 . The concentrations in sections 2 and 3 were similarly high. A total of seven individual PFC compounds were found in the liver of the brown trout, whereas only five were found in freshwater amphipods. This difference may be attributed to the accumulative property of the liver $[19,41,42]$.

\section{Brown trout muscle tissue}

The PFC concentrations in the samples of trout muscle are shown in Table 9. PFC with concentrations under the limit of quantification were not shown for the sake of clarity. It is notable that in contrast to the liver only PFOA and PFOS were detectable in muscle tissue.

Figure 6 shows a graphic representation of the PFC concentrations expanded measurement uncertainty in muscle tissue of brown trout.

It can be seen that PFOA concentrations are low compared to the liver, which is reflected in the total PFAS contamination. PFOS was only detectible in muscle tissue from trout in section 2 .

\section{Brown trout kidney tissue}

The PFC concentrations in the kidneys are shown in Table 10. Here again, PFC concentrations that are below the limit of quantification were not listed.

As with liver and muscle, PFOA was responsible for the main proportion of PFC in the kidney tissue (Fig. 7).

The results are quite similar to that from the liver (Fig. 5), whereby the PFC concentration in the liver is higher with regard to PFOA. Muscle tissue was found to have considerably lower concentrations of PFC than liver and kidney. This is in agreement with other studies of PFC contamination [41-44]. PFC accumulate in the kidneys, liver and gallbladder among other organs. In general, accumulation in muscle tissue is comparatively low and PFC are almost never found in fatty tissue [3]. As with the other brown trout organs, a concentration gradient along the sampled study sections was not apparent. Figures 4, 5, 6, 7 show a clear correlation between the PFC concentrations, study sections and indicator species. Whereas the PFC concentrations in the freshwater amphipods consistently decrease from section 1 to section 4 (Fig. 4), there is no such tendency in brown trout, when measuring the concentrations in individual organs. The habitat and behavior of these two organisms differ greatly. Amphipods exhibit a wide dietary spectrum and compared to trout are much more sedentary, as a rule 
only drifting or moving upstream a few meters per day within a given segment $[45,46]$. They are euryoecious (relatively tolerant of environmental variation) reach an age of up to 2 years and are at the beginning of the food chain in streams $[47,48]$. In contrast, brown trout may travel a number of kilometers per day when foraging and in spawning season. They mostly feed on insects and smaller fish, but also freshwater amphipods $[49,50]$. They are stenoecious, may reach an age of 15 years and as predators find their place at the top of the food chain in the stream [51]. These differences may influence the results of this study. Due to their migratory behaviour, uptake of substances by brown trout cannot be attributed to a particular region (here, individual study sections 2 to 4 of the stream). Instead, the fish visit different segments with possibly varying PFC concentrations (see Table 1), ingesting food that may also be more-or-less contaminated with PFC. Consequently, in direct comparison freshwater amphipods must be considered more site specific and as such are more meaningful indicators of PFC contamination within a defined segment of a stream. It must also be noted that the samples that were studied here were pooled. Therefore, no differentiation could be made depending upon age or size of the trout. The results show that of the two lead components in this study, PFOA makes up the largest part of the total PFC sum concentration in both the freshwater amphipods and in the liver, kidney and muscle of the brown trout. In other studies on liver and muscle of various organisms, PFOS was found at the highest concentrations; for instance in eel in European rivers (up to $498 \mu \mathrm{g} / \mathrm{kg}$ PFOS and up to $23 \mu \mathrm{g} / \mathrm{kg}$ PFOA in the liver; up to $18 \mu \mathrm{g} / \mathrm{kg}$ PFOS in muscle tissue) [44], roach (fish) in the Ems (up to $194 \mu \mathrm{g} / \mathrm{kg}$ PFOS and $<5 \mu \mathrm{g} / \mathrm{kg}$ PFOA in the liver; up to $40 \mu \mathrm{g} / \mathrm{kg}$ PFOS and $<5 \mu \mathrm{g} / \mathrm{kg}$ PFOA in muscle tissue) [43], polar bears in the Arctic (up to $3868 \mathrm{ng} / \mathrm{g}$ PFOS and up to $17.6 \mathrm{ng} / \mathrm{g}$ PFOA in the liver) [52] or wild pigs in Hessen (up to $1780 \mu \mathrm{g} /$ $\mathrm{kg}$ PFOS and up to $45 \mu \mathrm{g} / \mathrm{kg}$ PFOA in the liver; up to $28.6 \mu \mathrm{g} / \mathrm{kg}$ PFOS and up to $7.4 \mu \mathrm{g} / \mathrm{kg}$ PFOA in muscle tissue) [42]. In the present study we could not confirm these results. The highest concentrations of PFOS $(16.3 \mu \mathrm{g} / \mathrm{kg})$ were found in the kidneys of brown trout in section 2 , an indication that trout accumulate PFOS significantly more strongly, particularly in the liver and kidneys, than do freshwater amphipods. It is also notable that total (sum) of PFC concentrations in brown trout are lower than in freshwater amphipods (Figs. 4, 5, 6, 7). Since brown trout are at the end of the food chain in the stream they should theoretically accumulate more PFC and therefore have higher concentrations of these substances than freshwater amphipods $[3,53]$. The measurements of the freshwater amphipods, however, were made on pooled samples and the stomach contents were not removed.
Consequently, this may represent a source of error, since the stomach contents of the freshwater amphipods may also be contaminated with PFC. The contamination of this stream is most likely the result of the use of contaminated fertilizer [20]. Whereas high PFOS concentrations are primarily the result of contamination resulting from the use of fire-fighting foam, from sewage and from electroplating sludge, high PFOA concentrations in streams are among other things, connected with the use of fertilizers $[5,54]$. Since the section of the stream with the highest PFOA concentrations (study section 1) is in close proximity to agricultural lands this type of contamination is most likely the main source. The further downstream one goes the lower the individual PFC concentrations become. In the further course of the brook, individual PFC concentrations decrease. In addition, water analyses in the year 2011 showed that PFOA concentrations were higher than PFOS concentrations with an average of $8.9 \mu \mathrm{g} / \mathrm{l}$ for PFOA and $<0.05 \mu \mathrm{g} / \mathrm{l}$ for PFOS [55]. PFOA is also more water soluble than PFOS [56]. It is not possible to establish a causal relationship because water testing only represents a snapshot at the moment of sampling. The remaining PFCs such as PFPeA, PFHxA, PFHpA, PFNA and PFDA are found only at low concentrations or are not detectable. These substances make up between 5 and $23 \%$ of the total PFC concentration (according to the organ) in the trout (Fig. 8) and between 13 and $40 \%$ of total PFC concentration in the freshwater amphipods.

PFPeA, PFHxA and PFHpA are short-chain compounds $(<7$ perfluorinated carbon atoms), which are more mobile and spread through ground water and the soil more rapidly than do long-chain PFC ( $\geq 7$ perfluorinated carbon atoms), however they are scarcely bioaccumulated. Long-chain compounds such as PFNA and PFDA are prone to bioaccumulation, however this occurs slowly and are especially found in organisms that have been in contact with these compounds for an extended period of time [2,34]. Little is known about the short-chain compounds, beyond the fact that they are being used in industry as substitutes for long-chain PFC. There are, however, indications that these are possibly of no less relevance toxicologically than long-chain PFC. Short-chain PFC show a lower tendency to accumulate in organisms, however they are more mobile and can therefore more rapidly penetrate raw water, ground water and soil. Toxicological evaluation of short-chain PFC is not presently possible because current information on these substances is inadequate [57]. Limits exist, regulating the amount of PFC in fertilizers (the sum of $\mathrm{PFOA}+\mathrm{PFOS}=100 \mu \mathrm{g} / \mathrm{kg}$ TM) [13]. Guidelines or reference values have been recommended for drinking water (for example, for PFOS $\mathrm{TW}_{\mathrm{LW}}=0.1 \mu \mathrm{g} / \mathrm{l}$ ) [58]. So-called $\mathrm{PNEC}_{\mathrm{aquatic}}$ exist for surface waters. These describe a 


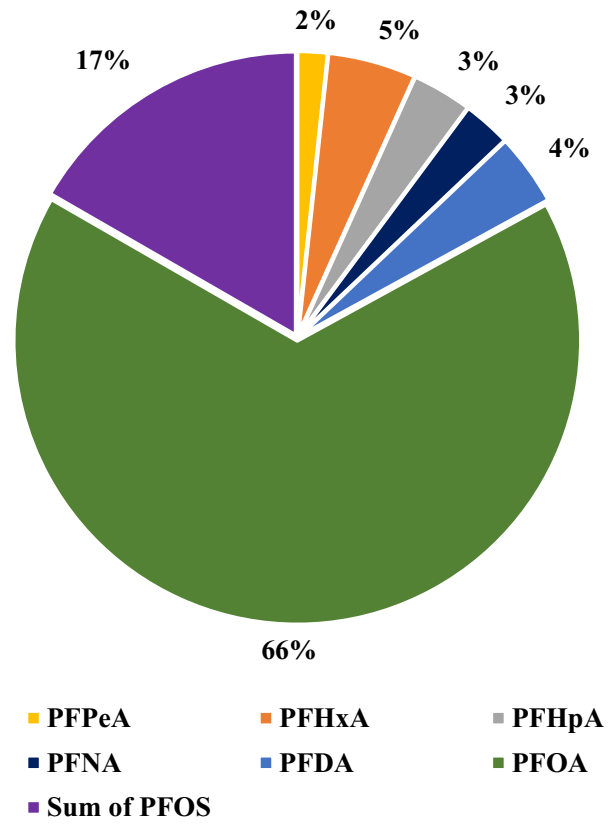

Fig. 8 Distribution of the PFC substances in the kidneys of brown trout (as example) from section 2

"predicted no effect concentration" (PNEC) in $\mu \mathrm{g} / \mathrm{l}$, Concentrations at which aquatic organisms are considered not to be adversely affected. The PNEC in surface waters for PFPeA is $320 \mu \mathrm{g} / \mathrm{l}$. No PNEC aquatic exist for PFOA, PFOS, PFNA and PFDA; however, these compounds are listed as SVHC (substances of very high concern) in Annex XIV of the European REACH (Registration, Evaluation, Authorization and Restriction of Chemicals) regulation. As such, threshold values cannot be defined since these substances represent a risk even in low concentrations due to their persistence [59]. The surface water directive stipulates, in form of an Environmental Quality standard (EQS) of natural biota, a maximal concentration for PFOS and its derivatives of $1 \mu \mathrm{g} / \mathrm{kg}$ in muscle tissue of fish. This concentration is exceeded in liver and kidneys of trout from stream sections 2 and 3. The biota EQS only refers to muscle tissue of fish. There is no biota EQS for kidney, liver or other organs of fish since these organs are not usually eaten. According to the environmental quality standard the protection target resource is primarily human health [60]. Under the REACH regulation PFOA was placed on the SVHC (substances of very high concern) list in the year 2013. There are no suitable measures for clean-up of surface PFC contamination, therefore protection, reduction and restriction measures must be followed [61, 62]. Most important, however, are measures that counter further introduction of PFC into the environment. This can primarily be ensured through preventative measures in the form of limits, guidelines, restrictions and bans.

\section{Conclusions}

The results presented show an insufficient hydro-ecological quality of the stream studied here. PFC contamination was detected, both in freshwater amphipods and in various organs of brown trout. The macroinvertebrate community should be analyzed tested in the future. Continual monitoring can provide an overview as to whether species numbers decline further. Especially, section 1 should be considered for restoration measures. It stands out among the other sections as a result of straightening and the lack of diversity. As a consequence, this section is in the greatest need of action. It must, however, also be noted that the other sections of the stream do not meet the requirements set by the Water Framework Directive for a "good" ecological condition. Freshwater amphipods would appear to potentially serve as bioindicators for PFC contamination in small streams. These organisms are ubiquitous in streams, even in those that are characterized by a lack of fish due to structural deficits. Freshwater amphipods are easier to obtain than fish samples since they do not require electrofishing. What is more, freshwater amphipods generally represent the majority of the biomass of benthic invertebrates, even in cases of poor ecological conditions. However, further studies will be required to validate these results. In addition, it will be necessary to show whether age (juvenile and adult) plays a role in the accumulation of PFC in the organism, and also whether there are species specific differences (Gammarus pulex und G. fossarum) in accumulation behavior. Since pooled samples were used it was not possible in this study to determine the age of the freshwater amphipods. This must be taken into account in future studies. Other species such as Gammarus roeseli and Gammarus tigrinus of freshwater amphipods should also be investigated regarding their PFC accumulation. Additionally, periodic on-site monitoring of PFC contamination should be undertaken, and dissemination of these substances in the environment should be counteracted. Furthermore, restorative measures must be developed. Surrounding streams, as well as contaminated agricultural areas are potential sources of PFC contamination and pose a potential risk for aquatic ecosystems. As a long-term approach, however, preventative measures alone come into question in order to eliminate the entry of these substances into the environment. Once PFC are introduced into the environment, their removal has proven to be extremely difficult. 


\section{Abbreviations}

6:2-FTS: Fluorotelomer sulfonic acid; 8:2-FTS: 8:2 fluorotelomer sulfonic acid; CPES: Current Potential Ecological Status; EQS: Environmental quality standard; ESI: Electrospray-ionization; HMUKLV: Hessian Ministry of the Environment, Climate Protection, Agriculture and Consumer Protection; KDONA: PFOAsurrogate; LAWA: German Working Group on water issues of the Federal States and the Federal Government; LC-MS/MS: Liquid chromatography-mass spectrometry/mass spectrometry; LGL: Bavarian Agency for Health and Food Safety; LoQ: Limit of quantification; MUNLV NRW: Ministry of the Environment, Agriculture, Nature and Consumer Protection of the State of North RhineWestphalia; NRW: North Rhine-Westphalia; PFBA: Perfluorobutanoic acid; PFBS: Perfluorobutane sulfonate; PFC: Per- und polyfluorinated chemicals; PFDA: Perfluorodecanoic acid; PFDDA: Perfluorododecanoic acid; PFHpA: Perfluoroheptanoic acid; PFHXA: Perfluorohexanoic acid; PFHxS: Perfluorohexane sulfonate; PFNA: Perfluorononanoic acid; PFOA: Perfluorooctanoic acid; PFOS: Perfluorooctane sulfonate; PFPeA: Perfluoropentanoic acid; PFUnDA: Perfluoroundecanoic acid; PN PNEC aquatic: Predicted No-Effect Concentration in the aquatic environment; QuEChERS: Quick-Easy-Cheap-Effective-Rugged-Safe; REACH: Registration, Evaluation, Authorization and Restriction of Chemicals; SVHC: Substances of very high concern; THM: Technische Hochschule Mittelhessen.

\section{Acknowledgements}

Special thanks go to the colleagues of the Bavarian Health and Food Safety Authority for their support during the investigations. In particular, we would like to thank the technical staff members Mrs. Müller and Mrs. Kawohl for the sample preparation and analysis of the samples and Dr. Wittig and Dr. Knapp for their scientific support of the investigations.

The electrofishing was carried out on our behalf. The persons who carried out the sampling have a license for electrofishing.

We wish to express our gratitude to Mr. Finke and Mr. Rohn from the "Community of Interest: Lake Eder" for carrying out the electrofishing and for related support.

\section{Authors' contributions}

UW, FS and TS performed the data calculations, participated in its coordination and drafted the manuscript. All authors read and approved the final manuscript.

\section{Funding}

Open access funding provided by Projekt DEAL.

\section{Availability of data and materials}

The datasets supporting the conclusions of this article are included within the article.

\section{Ethics approval and consent to participate}

Not applicable.

\section{Consent for publication}

Not applicable.

\section{Competing interests}

All co-authors have seen and agree with the contents of the manuscript and there is no financial interest to report. We certify that the submission is original work and is not under review for any other publication.

\section{Author details}

${ }^{1}$ Technische Hochschule Mittelhessen-University of Applied Sciences, Wiesenstr. 14, 35390 Giessen, Germany. ${ }^{2}$ Chemical and Veterinary, Analytical Institute Münsterland-Emscher-Lippe, Joseph-König-Str. 40, 48147 Munster, Germany.

Received: 14 April 2020 Accepted: 28 July 2020

Published online: 24 August 2020

\section{References}

1. OECD_Organisation for Economic Co-operation and Development (2018) Toward a new comprehensive global database of per- and polyfluoralkyl substances (PFASs): summary report on updating the OECD
2007 List of per- and polyfluoralkyl substances (PFASs). Ser Risk Manag 39:1-24

2. Buck RC, Franklin J, Berger U, Conder JM, Cousins IT, de Voogt $P$, Jensen AA, Kannan K, Mabury SA, van Leeuwen SPJ (2011) Perfluoroalkyl and polyfluoroalkyl substances in the environment: terminology, classification, and origins. Integr Environ Assess Manag 7(4):513-541

3. Fricke M, Lahl U (2005) Risk evaluation of perfluorinated surfactants as contribution to the current debate on the EU Commission's REACH document. Umweltwiss Schadst Forsch 17(1):36-49

4. Krafft MP, Riess JG (2015) Selected physicochemical aspects of polyand perfluoroalkylated substances relevant to performance, environment and sustainability_Part one. Chemosphere 129:4-19

5. Pabel U, Wölfle D, Lahrssen-Wiederholt M, Lampen A (2008) Toxikologie der Perfluoroctansäure (PFOA) und der Perfluoroctansulfonsäure (PFOS). J für Verbraucherschutz und Lebensmittelsicherheit 3(3):252-258

6. Stahl T, Falk S, Brunn H (2013) PFC —Anthropogen, ubiquitär und persistent: Nachweis von PFC in Trinkwasser, Lebens- und Futtermitteln sowie in Wildtieren. GIT Labor Fachz 4:222-225

7. Domingo JL, Nadal M (2019) Human exposure to per- and polyfluoroalkyl substances (PFAS) through drinking water: a review of the recent scientific literature. Environ Res 177:108648

8. OECD - Organisation for Economic Co-operation and Development (2002) Hazard Assessment of Perfluorooctane Sulfonate (PFOS) and its Salts

9. 3M Company (2000) Draft Initial Assessment Report Perfluorooctane Sulfonic Acid and its Salts-U.S. EPA Public Docket, AR226-0978

10. Benford D, de Boer J, Carere A, Di Domenico A, Johansson N, Schrenk D, Schoeters G, de Voogt P, Dellatte E (2008) Opinion of the Scientific Panel on Contaminants in the Food chain on perfluorooctane sulfonate (PFOS), perfluorooctanoic acid (PFOA) and their salts. EFSA J 653:1-131

11. Gellrich V, Stahl T, Knepper TP (2012) Behavior of perfluorinated compounds in soils during leaching experiments. Chemosphere 87(9):1052-1056

12. Gellrich V, Brunn H, Stahl T (2013) Perfluoroalkyl and polyfluoroalkyl substances (PFASs) in mineral water and tap water. J Environ Sci Health Part A 48(2):129-135

13. Stahl T, Gassmann M, Falk S, Brunn H (2018) Concentrations and distribution patterns of perfluoroalkyl acids in sewage sludge and in biowaste in Hesse, Germany. J Agric Food Chem 66(39):10147-10153

14. Kowalczyk J, Ehlers S, Fürst P, Schafft H, Lahrssen-Wiederholt M (2012) Transfer of perfluorooctanoic acid (PFOA) and perfluorooctane sulfonate (PFOS) from contaminated feed into milk and meat of sheep: pilot study. Arch Environ Contam Toxicol 63(2):288-298

15. Kowalczyk J, Ehlers S, Oberhausen A, Tischer M, Fürst P, Schafft H, Lahrssen-Wiederholt M (2013) Absorption, distribution, and milk secretion of the perfluoroalkyl acids PFBS, PFHxS, PFOS, and PFOA by dairy cows fed naturally contaminated feed. J Agric Food Chem 61(12):2903-2912

16. Fromme H, Tittlemier SA, Völkel W, Wilhelm M, Twardella D (2009) Perfluorinated compounds - exposure assessment for the general population in western countries. Int J Hyg Environ Health 212(3):239-270

17. Hemfler M, Weidner E, Emmerich K, Stanislava G (2008) Perfluorierte Chemikalien (PFC) in Hessen. Untersuchungsprogramm des HLUG-Hessisches Landesamt für Umwelt und Geologie

18. LANUV — Landesamt für Natur, Umwelt und Verbraucherschutz Nordrhein-Westfalen (2011) Verbreitung von PFT in der Umwelt: UrsachenUntersuchungsstrategie-Ergebnisse-Maßnahmen. LANUV-Fachbericht 34

19. Falk S, Failing K, Georgii S, Brunn H, Stahl T (2014) Tissue specific uptake and elimination of perfluoroalkyl acids (PFAAs) in adult rainbow trout (Onchorhynchus mykiss) after dietary exposure. Chemosphere 129:150-156

20. Marbach HB (2016) Das Stoffverhalten von perfluorierten Chemikalien (PFC) in den Wirkungspfaden Boden-Grundwasser und Boden-Pflanze unter besonderer Berücksichtigung von Perfluoroctansulfonat (PFOS). Goethe-Universität Frankfurt am Main, Masterthesis

21. HLNUG - Hessian Agency for Nature Conservation, Environment and Geology (2019) Water Framework Policy Viewer. http://wrrl.hessen.de/ mapapps/resources/apps/wrrl/index.html?lang=de. Accessed 06 Jan 2020 
22. Länderarbeitsgemeinschaft Wasser LAWA- (2000) Gewässerstrukturgütekartierung in der Bundesrepublik Deutschland: Verfahren für kleine und mittelgroße Fließgewässer. Kulturbuchverlag, Empfehlung

23. European Parliament \& Council (2000) Water Framework Directive 2000/60/EC

24. Meier C, Haase P, Rolauffs P, Schindehütte K, Schöll F, Sundermann A, Hering D (2006c) Methodisches Handbuch Fließgewässerbewertung: Handbuch zur Untersuchung und Bewertung von Fließgewässern auf der Basis des Makrozoobenthos vor dem Hintergrund der EG-Wasserrahmenrichtlinie

25. Bauernfeind E, Humpesch UH (2001) Die Eintagsfliegen Zentraleuropas (Insecta Ephemeroptera): Bestimmung und Ökologie. Verl. Naturhist. Mus, Wien

26. LANUV—Landesamt für Natur, Umwelt und Verbraucherschutz Nordrhein-Westfalen (2010) Taxonomie für die Praxis. Bestimmungshilfen-Makrozoobenthos (1). LANUV-Arbeitsblatt 14

27. Nagel P (1989) Bildbestimmungsschlüssel der Saprobien: Makrozoobenthon. G. Fischer, Stuttgart

28. Sundermann A, Lohse S (2004) Bestimmungsschlüssel für die aquatischen Zweiflügler (Diptera) in Anlehnung an die Operationelle Taxaliste für Fließgewässer in Deutschland: Methodenstandardisierung Makrozoobenthos. Forschungsinstitut Senckenberg

29. Waringer J, Graf W (2011) Atlas der mitteleuropäischen Köcherfliegenlarven. Erik Mauch Verlag, Dinkelscherben

30. Meier C, Haase P, Rolauffs P, Schindehütte K, Schöll F, Sundermann A, Hering D (2013) ASTERICS—einschließlich PERLODES—Softwarehandbuch. Version 4

31. VDI 4230 Blatt 4 (2013) Biologische Verfahren zur Erfassung von Umweltbelastungen (Bioindikation): Passives Biomonitoring mit Fischen als Akkumulationsindikatoren. Verein Deutscher Ingenieure, Beuth

32. DIN EN 14011 (2003) Probenahme von Fisch mittels Elektrizität: Deutsche Fassung EN 14011. Deutsches Institut für Normung e. V, Berlin

33. Anastassiades M, Lehotay SJ, Stajnbahe D, Schenck FJ (2003) Fast and easy multiresidue method employing acetonitrile extraction/partitioning and "dispersive solid-phase extraction" for the determination of pesticide residues in produce. J AOAC Int 2:412-431

34. Carlsson P, Crosse JD, Halsall C, Evenset A, Heimstad ES, Harju M (2016) Perfluoroalkylated substances (PFASs) and legacy persistent organic pollutants (POPs) in halibut and shrimp from coastal areas in the far north of Norway: small survey of important dietary foodstuffs for coastal communities. Mar Pollut Bull 105(1):81-87. https://doi.org/10.1016/j.marpo |bul.2016.02.053 Epub 2016 Mar 2 PMID: 26948293

35. Dahm V, Kupilas B, Rolauffs P, Hering D, Haase P, Kappes H, Leps M, Sundermann A, Döbbelt-Grüne S, Hartmann C, Koenzen U, Reuvers C, Zellmer U, Zins C \& Wagner F (2014) Hydromorphologische Steckbriefe der deutschen Fließgewässertypen. Anhang 1 von "Strategien zur Optimierung von Fließgewässer-Renaturierungsmaßnahmen und ihrer Erfolgskontrolle". Umweltbundesamt

36. Pottgiesser T, Sommerhäuser M (2008) Steckbriefe der deutschen Fließgewässertypen: Typ 5: Grobmaterialreiche, silikatische Mittelgebirgsbäche

37. Meier C, Haase P, Rolauffs P, Schindehütte K, Schöll F, Sundermann A, Hering D (2006b) Kurzdarstellung "Core Metrics Makrozoobenthos"

38. Meier C, Haase P, Rolauffs P, Schindehütte K, Schöll F, Sundermann A, Hering D (2006a) Kurzdarstellung "Bewertung Makrozoobenthos". Typ 5: Grobmaterialreiche, silikatische Mittelgebirgsbäche

39. Essl F, Rabitsch W, Rahmstorf S (2013) Biodiversität und Klimawandel: Auswirkungen und Handlungsoptionen für den Naturschutz in Mitteleuropa. Springer, Berlin

40. Pulg U (2008) Laichplätze der Bachforelle (Salmo trutta) in der Moosachdie Bewertung ihrer Funktionsfähigkeit, ihre Degradierung und ihre Restaurierung. Dissertation, Technische Universität München

41. Riebe RA, Falk S, Georgii S, Brunn H, Failing K, Stahl T (2016) Perfluoroalkyl acid concentrations in livers of fox (Vulpes vulpes) and chamois (Rupicapra rupicapra) from Germany and Austria. Arch Environ Contam Toxicol 71(1):7-15

42. Stahl T, Falk S, Failing K, Berger J, Georgii S, Brunn H (2012) Perfluorooctanoic acid and perfluorooctane sulfonate in liver and muscle tissue from wild boar in Hesse, Germany. Arch Environ Contam Toxicol 62(4):696-703

43. NMU—Niedersächsisches Ministerium für Umwelt und Klimaschutz (2009) Perfluorierte Tenside (PFT) im Gewässer, Abwasser und
Klärschlamm in Niedersachsen: Anlass, allgemeine Stoffeigenschaften und Bewertungskriterien, Untersuchungsergebnisse und Maßnahmen

44. Santillo D, Walters A, Perivier H (2006) Presence of perflorinated chemicals in eels from 11 European countries: Investigating the contamination of the European eel with PFC, substances used to produce non-stick and water-repellant coatings for a multitude of products. Greenpeace Report

45. Bohle HW (1995) Spezielle Ökologie. Limnische Systeme. Springer, Berlin

46. Meijering M (1972) Experimentelle Untersuchungen zur Drift und Aufwanderung von Gammariden in Fließgewässern. Archiv für Hydrobiologie 70(2):133-205

47. Eggers T, Martens A (2001) A key to the freshwater Amphipoda (Crustacea) of Germany. Lauterbornia 42:1-68

48. Grabowski M, Bacela K, Konopacka A (2007) How to be an invasive gammarid (Amphipoda: gammaroidea) — comparison of life history traits. Hydrobiologia 590(1):75-84

49. Lelek A, Buhse G (1992) Fische des Rheins:- - früher und heute -. Springer, Berlin

50. Jungwirth M, Haidvogl G, Moog O, Muhar S, Schmutz S (2003) Angewandte Fischökologie an Fließgewässern. Facultas-Verlag, Wien

51. Lobón-Cerviá J, Sanz N (2018) Brown trout: biology, ecology and management. John Wiley \& Sons, Incorporated, Hoboken

52. Smithwick M, Mabury SA, Solomon KR, Sonne C, Martin JW, Born EW, Dietz R, Derocher AE, Letcher RJ, Evans TJ, Gabrielsen GW, Nagy J, Stirling I, Taylor MK, Muir DCG (2005) Circumpolar study of perfluoroalkyl contaminants in polar bears (Ursus maritimus). Environ Sci Technol 39(15):5517-5523

53. Kannan K, Koistinen J, Beckmen K, Evans T, Gorzelany JF, Hansen KJ, Jones PD, Helle E, Nyman M, Giesy JP (2001) Accumulation of perfluorooctane sulfonate in marine mammals. Environ Sci Technol 35(8):1593-1598

54. Ulrich H, Freier KP, Gierig M (2016) Getting on with persistent pollutants: Decreasing trends of perfluoroalkyl acids (PFAAs) in sewage sludge. Chemosphere 161:527-535. https://doi.org/10.1016/j.chemospher e.2016.07.048 (Epub 2016 Jul 26)

55. Krippner J (2012) Aufnahme und Verteilung von perfluorierten Chemikalien (PFC) in Mais (Zea mays) in Abhängigkeit von pH-Wert und Kettenlänge. Justus-Liebig-Universität Gießen, Masterthesis

56. Bizkarguenaga E, Zabaleta I, Mijangos L, Iparraguirre A, Fernández LA, Prieto A, Zuloaga O (2016) Uptake of perfluorooctanoic acid, perfluorooctane sulfonate and perfluorooctane sulfonamide by carrot and lettuce from compost amended soil. Sci Total Environ 571:444-451. https://doi. org/10.1016/j.scitotenv.2016.07.010

57. BMUB - Bundesministerium für Umwelt, Naturschutz, Bau und Reaktorsicherheit (2017) Bericht zu perfluorierten Verbindungen. Reduzierung/ Vermeidung, Regulierung und Grenzwerte, einheitliche Analyse- und Messverfahren für fluororganische Verbindungen. https://www.umwel tministerkonferenz.de/umlbeschluesse/umlaufBericht2017_19.pdf. Accessed 15 July 2020

58. UBA (2017) Fortschreibung der vorläufigen Bewertung von per- und polyfluorierten Chemikalien (PFC) im Trinkwasser: empfehlung des Umweltbundesamtes nach Anhörung der Trinkwasserkommission. Bundesgesundheitsblatt, Gesundheitsforschung, Gesundheitsschutz 60(3):350-352

59. Von der Trenck KT, Konietzka R, Biegel-Engler A, Brodsky J, Hädicke A, Quadflieg A, Stockerl R, Stahl T (2018) Significance thresholds for the assessment of contaminated groundwater: perfluorinated and polyfluorinated chemicals. Environ Sci Eur 30:19. https://doi.org/10.1186/s1230 2-018-0142-4

60. OGewV (2016):Verordnung zum Schutz der Oberflächengewässer (Oberflächengewässerverordnung-OGewV)

61. Frauenstein J (2018) PFC — nur eine neue Herausforderung für die Sanierung von Boden und Grundwasser. 11. Fachtagung ChloroNet-Bauen und Sanieren. Umweltbundesamt

62. Meßmer E (2017) Brennpunkt PFC—Mittelbaden. Fakten, Thesen \& Schlussfolgerungen: per- und polyfluorierte Chemikalien (PFC) in Trinkwasser und Landwirtschaft. Grünes Forum Baden e.V.

\section{Publisher's Note}

Springer Nature remains neutral with regard to jurisdictional claims in published maps and institutional affiliations. 